Regional Paths of Development

Author(s): Gary Gereffi and Stephanie Fonda

Source: Annual Review of Sociology, Vol. 18 (1992), pp. 419-448

Published by: Annual Reviews

Stable URL: http://www.jstor.org/stable/2083461

Accessed: 18-09-2015 12:04 UTC

Your use of the JSTOR archive indicates your acceptance of the Terms \& Conditions of Use, available at http://www.jstor.org/page/ info/about/policies/terms.jsp

JSTOR is a not-for-profit service that helps scholars, researchers, and students discover, use, and build upon a wide range of content in a trusted digital archive. We use information technology and tools to increase productivity and facilitate new forms of scholarship. For more information about JSTOR, please contact support@jstor.org. 


\section{REGIONAL PATHS OF DEVELOPMENT}

\section{Gary Gereffi and Stephanie Fonda}

Department of Sociology, Duke University, Durham, North Carolina 27706

KEY WORDS: East Asia, Latin America, South Asia, sub-Saharan Africa, paths of development, development theories

\section{Abstract}

Development is the key challenge facing human society. The essence of development is to improve the quality of life, yet the striking technological revolutions of recent years have not resulted in better living conditions for most of the world's population. These contrasts are not limited to comparisons between advanced industrial and developing societies; they are also reflected in starkly differing patterns of development within the third world.

Five broad theoretical perspectives frame much of the literature on regional paths of development: neoclassical economics, world-systems/dependency theories, the developmental state, institutional analysis, and marxism. While these approaches are general in nature, there are marked affinities between individual theories and the experience of particular regions in the third world.

Our review focuses on four third-world regions: Latin America, East Asia, South Asia, and sub-Saharan Africa. East Asia comes out on top according to almost all indicators of economic and social development, followed by Latin America, South Asia, and, at a considerable distance from the rest, Africa. The comparative analysis of the paths of development followed in these regions not only generates useful insights about concrete development processes; it also serves as a tool for refining development theory itself, and points to promising new areas of research. 


\section{INTRODUCTION}

The twentieth century has seen breathtaking technological changes. Since the era of horse-drawn carriages and the introduction of the first telephones at the turn of the century, we have witnessed modern transportation and communications revolutions that now allow us to cross oceans in supersonic passenger aircraft in a matter of hours, send documents by facsimile machines anywhere in the world within minutes, and explore the outer reaches of the universe. Despite these staggering accomplishments, in 1991 "more than 1 billion people, one-fifth of the world's population, live on less than one dollar a day - a standard that Western Europe and the United States attained two hundred years ago" (World Bank 1991:1).

Why is there such a sharp contrast between technological development and social underdevelopment? Is the gap between rich and poor countries widening or narrowing? How have the different regions of the world been coping with the development challenge? These questions are difficult not only because of the immense diversity of human experiences around the globe, but also because the concept of development does not lend itself to easy definition or measurement.

The essence of development is to improve the quality of life. This generally calls for higher incomes, which are the result of gains in productivity and technological advances among nations. Economic progress, in turn, depends on a number of other development objectives: better education, improved health and nutrition, a cleaner environment, a reduction of poverty, more equality of opportunity, an enhancement of individual freedoms, and a richer cultural environment. The multidimensional nature of development, and the fact that these desired objectives do not necessarily occur together, help to account for some of the disparities in international living standards and the trade-offs in national development outcomes. But many of the contradictory aspects of global development still remain, sparking intense debates that vary according to the geographical regions and countries one is considering.

\section{Focus of Our Review}

The objective of this paper is to examine the current controversies and evidence on regional paths of development in the third world, and to draw out some of the theoretical implications of the comparative study of these regional trajectories. The review consists of three main parts. First, we outline five major theoretical perspectives that have been used to analyze third world development: neoclassical economics, world-systems/dependency theories, the developmental state, institutional analysis, and marxism. In practice, each of these perspectives has been applied selectively, thus illuminating certain processes of change while downplaying others. Second, we utilize statistical 
comparisons and a variety of case study materials to trace the development trajectories of four major third world regions in the 1980s: Latin America, East Asia, South Asia, and sub-Saharan Africa. From this comparison, it is apparen that regional paths of development reflect very different modes of integration into the world economy. Finally, we show that comparing these regional development experiences not only generates useful insights about concrete development processes, it also serves as a tool for refining broad theories of development and pointing to new areas of research.

\section{A Note on Bibliographic Sources}

Although there is a wealth of material on the development of the four regions we have selected, a count of all the articles that appeared in American Sociological Review, American Journal of Sociology, and Social Forces from 1980 to 1990 indicates that much of the literature addressing major third world topics does not appear in the major sociological journals. We also examined all the book reviews in Contemporary Sociology during the same time period in order to get an idea of the number of books that have been published recently on the third world.

Articles that looked at one or more third world countries were relevant for our purposes. The 11-year timeframe was divided into two blocks (19801985 and 1986-1990) to check for differences in the frequency of articles published on this topic.

We found that $4 \%$ to $6 \%$ of the total number of articles and book reviews published in the sociological journals included third world cases. These percentages were remarkably stable across all four journals and the two time periods as well. Asia was the most frequently studied region in the articles that appeared in the American Sociological Review, the American Journal of Sociology, and Social Forces, while the greatest number of third world books reviewed in Contemporary Sociology were concerned with Latin America. These regional preferences were consistent for both time periods. Although these statistics are admittedly crude, they indicate the need to look beyond mainstream sociological sources for relevant literature on our topic.

\section{THEORETICAL PERSPECTIVES AND CONTROVERSIES}

Theories of development have evolved rapidly during the past decade. In an effort to capture the major sources of controversy in the development field, this review highlights five broad theoretical perspectives that frame much of the literature on regional paths of development: neoclassical economics, world-systems/dependency theories, the developmental state, institutional analysis, and marxism. These theoretical approaches diverge in their assumptions, levels of analysis, empirical assessments, and prescriptions for change 
(see So 1990). However, the internal evolution of these theories in the 1980s, and their tendency to be selectively applied to the geographical areas they fit best, provide us with important benchmarks for assessing not only the development experiences of these regions but also their impact on development theory itself. (For a discussion of similar theoretical categories with regard to Africa, see Lubeck, this volume.)

The regional development literature in the 1980s reflects the main features of what has been called "the new comparative political economy" (see Evans \& Stephens 1988). Development paths are viewed as historically contingent, and there is an emphasis on the role of external as well as institutional factors in shaping domestic development outcomes. Because of their concern with problems of conjunctural causation and multiple paths to the same point, researchers often prefer comparisons of small numbers of cases or the analysis of single cases set in a comparative framework (see Ellison \& Gereffi 1990). Historical and comparative approaches thus serve as "orienting strategies" or directives in the establishment of theoretical research programs that evolve as they attempt to explain new patterns of development in a global setting (Wagner \& Berger 1985).

NEOCLASSICAL ECONOMICS There has been a resurgence in the political impact of neoclassical economics in the third world during the 1980s. This perspective has been closely associated with the World Bank and its prominent sister institution, the International Monetary Fund (IMF), which often condition their lending decisions on the willingness of developing nations to conform to neoclassical economic policies and related institutional changes.

The neoclassical framework advocates laissez-faire trade policies (e.g. low tariffs, few import controls, and no export subsidies), a free labor market, stable real exchange rates, competitive market structures, wage restraint, and a limited, non-interventionist role for the government in the economy. Neoclassical economists also tend to defend traditional notions of comparative advantage in which resource-rich third world countries are encouraged to concentrate on exports of raw materials and labor-intensive manufactures, and to abandon attempts to promote advanced industrialization through industrial policies that seek to improve a country's position in the existing international division of labor.

The espousal of neoclassical economics by international financial organizations like the World Bank and the IMF is particularly significant because they have the policy networks to diffuse their message to a wide range of countries, and the economic resources to make their opinions matter. Frequently, the preferences of these institutions are framed in terms of explicit cross-regional comparisons. The World Bank's World Development Report, 1987, for instance, argues that the outward-oriented development strategies of East Asia 
are far superior in terms of exports, economic growth, and employment to the inward-oriented development strategies pursued in Latin America, South Asia, and elsewhere (World Bank 1987: Ch. 5; see also Balassa 1981: 1-26; Balassa et al 1986). The clear implication of the World Bank's argument is that the newly industrializing countries of East Asia (South Korea, Taiwan, Hong Kong, and Singapore) are a model to be emulated throughout the developing world.

The available cross-country evidence, however, suggests a more cautious assessment concerning the performance of outward-oriented and inwardoriented economies. For example, the former tend to do better when the world economy is expanding, while an inward-orientation is more successful when world demand grows slowly. Furthermore, serious doubts have been raised about a variety of other issues concerning the definitions, measurements, and causal mechanisms that underlie the generalizability of the neoclassical claims (see Wade 1990: 16-22 for a succinct overview of this debate).

WORLD-SYSTEMS/DEPENDENCY THEORIES World-systems theory, which drew heavily on earlier marxian ideas of imperialism and capitalist exploitation, has been closely associated with the work of Immanuel Wallerstein $(1974,1979,1989)$. This theory postulates a hierarchy made up of core, semiperipheral, and peripheral nations in which upward or downward mobility is conditioned by the resources and obstacles affecting distinct sets of nations. According to this perspective, a country's mode of incorporation into the capitalist world-economy is the key variable that determines national development outcomes. Leaving one structural position implies taking on a new role in the prevailing division of labor, rather than escaping from the system. Thus the possibilities for autarchic paths of development are quite limited.

World-systems theory has given rise to a comprehensive sociology of development that cuts across all world regions. The periphery and semiperiphery are composed predominantly of countries from Africa, Asia, and Latin America, while the core nations are concentrated in Europe, North America, and most recently, Japan. Countries that fall within the semiperiphery, such as South Korea and Taiwan in East Asia, Mexico and Brazil in Latin America, India in South Asia, and Nigeria and South Africa in Africa, are particularly important to the theory because they promote the stability and legitimacy of the three-tiered world-system (Wallerstein 1974, Arrighi \& Drangel 1986, Arrighi 1990). Nonetheless, the extreme diversity of the countries found in the core, semiperiphery, and periphery calls for a more disaggregated analysis of national development trajectories to understand why similarly situated countries respond differently to external economic challenges. 
Dependency theory, which emerged in the 1960s in opposition to most of the claims of modernization theory, also emphasizes external linkages but with a more specific focus on third world nations. Whereas modernization studies tended to argue that the salvation of the periphery lay in closer investment and trade ties with the core nations, the dependency approach highlights the exploitative potential of these relationships for the periphery (Valenzuela \& Valenzuela 1978). Evidence from a number of Latin American and African cases seemed to indicate that links to the center were the source of many of the third world's problems, rather than a solution.

Dependency theory qualified its initial claims with a new wave of case studies in the 1970s and 1980s that diverged sharply from earlier "stagnationist" views that claimed dependency could only lead to underdevelopment and revolution (see Gereffi 1983: Ch. 1 and Haggard 1989 for an overview of this debate). The notion of dependent development stresses the fact that structural dependency on foreign capital and external markets in the more advanced countries of the third world constrains and distorts, but is not incompatible with, capitalist economic development (Biersteker 1978, Evans 1979, Gold 1981, Lim 1985, Bradshaw 1988). Industry case studies adopted bargaining perspectives that looked at the interaction between the state, multinational corporations, and national business elites in shaping local development options in the relatively dynamic manufacturing sectors (Gereffi 1983, Bennett \& Sharpe 1985, Newfarmer 1985). This bargaining framework sparked a vigorous debate about the limits of dependency analysis and the possibilities for dependency reversal (see Grieco 1984, Encarnation 1989).

THE DEVELOPMENTAL STATE Most development theories dealing with late industrialization, dependent development, or unequal exchange in the worldsystem give a great deal of attention to the state. Their main concern is to clarify the role of the state in exercising direct and indirect influence on the economic growth of industrial late-comers. The concept of a "developmental state" focuses on the political will, the ideological coherence, the bureaucratic instruments, and the repressive capacity needed to formulate and implement effective economic policies to promote high-speed capitalist growth.

The earliest versions of the developmental-state perspective examined the performance of peak economic agencies in postwar Japan (see Johnson 1982, 1987, Friedman 1988). This literature is now quite broad in scope, however, and it contributes to a comparative understanding of the politics of late industrialization in different regions of the world (see Wade \& White 1984, Chu 1989, Wade 1990, and Collier 1979 for useful overviews of these issues).

Most third world nations have been characterized by authoritarian regimes, but the nature and evolution of these political systems and their ability to 
effectively implement national development strategies vary by region. In Latin America, attention has shifted from trying to explain the rise of bureaucratic-authoritarian regimes that emphasized advanced importsubstituting industrialization in the 1960s and 1970s (Collier 1979), to accounting for "redemocratization"-i.e. the much heralded series of bloodless transitions from authoritarian to democratic rule that occurred in South America during the mid to late 1980s (O’Donnell et al 1986, Stepan 1988). It is too early to tell, however, whether democratic governments and their more export-oriented development strategies will fare better than their predecessors in alleviating the persistent problems of poverty and social marginalization, while continuing to try to attract foreign capital.

In East Asia, there have been attempts to reformulate the bureaucraticauthoritarian model to explain the greater coercive capacity and more exclusionary character of the developmental state in countries like South Korea and Taiwan, as well as the impact of the distinctive East Asian regional configuration resulting from the dual influence of US hegemony and the Japanese economy (Cumings 1984, 1989). Gradual political liberalizations within the region, together with the chilling effects of the Tiananmen Square crackdown on the prodemocracy movement in China, have occupied center stage in the last few years. This has left political analysts groping for compelling comparative explanations of how the timing and character of democratization and industrialization in East Asia as well as Latin America are related to domestic factors (such as economic policy, social structure, and political coalitions) and to the position of each region in the world-system.

In Africa, patrimonial political regimes are disproportionately influenced by small "presidential cliques" and the absence of relatively autonomous, development-oriented bureaucracies. This has rendered the state incapable of formulating and implementing the kinds of national economic strategies found in other third world regions (Evans 1989b, Lubeck, this volume).

INSTITUTIONAL ANALYSIS The study of institutions is undergoing a revival in the social sciences, although institutionalism has disparate meanings in different disciplines. In organization theory and sociology, the new institutionalism entails "a rejection of rational-actor models, an interest in institutions as independent variables, a turn toward cognitive and cultural explanations, and an interest in properties of supraindividual units of analysis that cannot be reduced to aggregations or direct consequences of individuals' attributes or motives" (DiMaggio \& Powell 1991:8). Institutionalism has had a direct impact on the study of third world industrialization in two main areas: the social embeddedness of economic networks, and the role of culture.

Economic networks illustrate how formal and informal business arrangements are organized in different societies. Economic transactions are struc- 
tured by different principles of social coordination that lie between the organizational extremes of "markets" (i.e. externalized transactions between independent firms) and "hierarchies" (i.e. a series of internalized transactions within the organizational structure of a single firm) (Williamson 1985). The concept of "networks" elaborates this typology by focusing on decentralized but repetitive and stable transactions between organizations that usually are knit together by social bonds of kinship, ethnicity, or trust (Granovetter 1985). Within the third world, economic networks have been a key to understanding the flexibility and dynamism embodied in various kinds of production structures, such as East Asian enterprise groups (Hamilton et al 1987, Hamilton \& Biggart 1988, Orrú et al 1991), international subcontracting arrangements and regional divisions of labor in global industries (Henderson 1989, Doner 1991), and the burgeoning informal sectors of developing societies (Portes et al 1989).

The rapid growth of the East Asian newly industrializing countries also has refocused attention on the role of culture in national development (Ellison \& Gereffi 1990:394-97, Gereffi 1989b). A number of writers argue that Confucianism confers certain advantages over other traditions in the quest for economic advancement. Because Confucian beliefs stress the importance of sobriety, education, achievement, and reciprocal social obligations, these characteristics are thought to have facilitated the national consensus around high-speed economic growth evident in Japan and the East Asian newly industrializing countries since the 1950s and 1960s (Johnson 1982, Berger \& Hsiao 1988). In Latin America, a divergent set of cultural norms based upon an Ibero-Catholic or Hispanic heritage has been identified as impeding the economic progress of the region (see Valenzuela \& Valenzuela 1978).

Sweeping arguments about the impact of culture on development in East Asia, Latin America, or other third world areas run into a variety of problems, however. First, regions are not culturally homogeneous; this is particularly true of East Asia with its mix of Confucianism, Taoism, and Buddhism as well as a significant Christian minority. More importantly, in terms of the timing of high-speed growth, both the Confucian and Ibero-Catholic traditions have existed for centuries. However, the dynamic shifts in economic performance in both regions, especially in East Asia, have occurred primarily in the past few decades. Furthermore, the same Confucian beliefs that now are said to facilitate rapid industrialization in East Asia were criticized by several generations of Western scholars for inhibiting economic development (see Hamilton \& Kao 1987).

A more sophisticated cultural interpretation is needed. Cultural factors are historically situated and shaped by institutions. Symbols, stories, rituals, and world-views are continuously adapted and recombined to solve different kinds of problems (Swidler 1986). The construction of institutionalized, rational- 
ized "myths" becomes a powerful tool in promoting structual changes among existing organizations and creating new organizational forms (Meyer \& Rowan 1991). Culture probably is most important in constructing strategies of action and outlining an acceptable range of solutions to development problems, whether they are optimally efficient or not, rather than in explaining specific development outcomes.

MARXISM Finally, marxian perspectives focus on the exercise of power by dominant elites. They draw attention to patterns of inequality common to most large-scale societies and emphasize the role of the state in maintaining the system of private property that gives rise to class conflict. Marxism argues that under capitalism, economic growth is contingent upon profits accumulated through the exploitation of low-wage labor and the repression of subordinated classes.

Marxian arguments are prominent in several of the theoretical approaches discussed above, especially the world-systems (Wallerstein 1974, 1979, Arrighi 1990), dependency (Amin 1976, Evans 1979, Kim 1987), and some state-centered perspectives (Cumings 1989). Traditional marxism seems to have lost ground as a general theory of capitalist development and underdevelopment, however, due to the inability of third world revolutionary movements to institutionalize successful socialist development models and to the recent fragmentation of the Soviet Union and the socialist bloc in Eastern Europe.

With this backdrop, the remainder of our review highlights distinctive regional paths of development and indicates the implications of these patterns for refining general development theories.

\section{THIRD WORLD REGIONS COMPARED: A STATISTICAL OVERVIEW}

Sub-Saharan Africa, East Asia, South Asia, and Latin America have sharply contrasting development profiles, although they are frequently grouped together under the third world label. These differences are exemplified by various economic and social indicators of development (see Tables 1 and 2).

In terms of the level and rate of growth of GNP per capita, East Asia has outdistanced the other regions of the third world. Latin America had a regional GNP per capita of $\$ 1,950$ in 1989, followed by East Asia (\$540), sub-Saharan Africa (\$340), and South Asia (\$320) (Table 1). However, the perspective changes considerably if we separate China from the East Asian newly industrializing countries. China has a GNP per capita of $\$ 350$, which is similar to that of sub-Saharan Africa and South Asia, but the East Asian entrepôt city-states of Hong Kong and Singapore rank among the World 
Table 1 Economic and social indicators by country and region

GNP per capita

\begin{tabular}{|c|c|c|c|c|c|c|c|}
\hline \multirow[b]{2}{*}{ Region/Country } & \multirow{2}{*}{$\begin{array}{c}\text { Population } \\
\text { (millions) } \\
\text { mid-1989 }\end{array}$} & \multirow{2}{*}{$\begin{array}{c}\text { Area } \\
\text { (thousands of } \\
\text { square miles) }\end{array}$} & \multirow{2}{*}{$\begin{array}{l}\text { Population } \\
\text { Density } \\
\text { (people per } \\
\text { square miles) }\end{array}$} & \multicolumn{2}{|c|}{$\begin{array}{c}\text { GDP } \\
\text { (US\$ billions) }\end{array}$} & \multicolumn{2}{|c|}{ Dollars } \\
\hline & & & & 1980 & 1989 & 1980 & 1989 \\
\hline Sub-Saharan Africa ${ }^{a}$ & 480.4 & 23,066 & 20.8 & NA & 161.8 & NA & 340 \\
\hline Nigeria & 113.8 & 924 & 123.2 & 91.1 & 28.9 & 1,010 & 250 \\
\hline Tanzania & 23.8 & 945 & 25.2 & 4.4 & 2.5 & 280 & 130 \\
\hline Kenya & 23.5 & 580 & 40.5 & 6.0 & 7.1 & 420 & 360 \\
\hline East Asia ${ }^{\mathrm{b}}$ & $1,552.4$ & 15,582 & 99.6 & NA & 895.2 & NA & 540 \\
\hline People's Republic of China & $1,113.9$ & 9,561 & 116.5 & $252.2^{\mathrm{f}}$ & 417.8 & 290 & 350 \\
\hline South Korea & 42.4 & 99 & 428.3 & 58.3 & 211.9 & 1,520 & 4,400 \\
\hline Taiwan & 20.1 & 36 & 558.3 & 41.5 & 148.5 & 2,340 & 7,510 \\
\hline South Asia ${ }^{c}$ & $1,130.8$ & 5,158 & 219.2 & NA & 317.2 & NA & 320 \\
\hline$\overline{\text { India }}$ & 832.5 & 3,288 & 253.2 & 142.0 & 235.2 & 240 & 340 \\
\hline Latin America \& Caribbean $^{\mathrm{d}}$ & 421.2 & 20,385 & 20.7 & NA & 809.2 & NA & 1,950 \\
\hline$\overline{\text { Brazil }}$ & 147.3 & 8,512 & 17.3 & 210.7 & $319.2^{f}$ & 2,050 & 2,540 \\
\hline Mexico & 84.6 & 1,958 & 43.2 & 166.7 & 200.7 & 2,090 & 2,010 \\
\hline
\end{tabular}

Notes: ${ }^{a}$ Sub-Saharan Africa refers to all countries south of the Sahara except South Africa.

${ }^{\mathrm{b}}$ East Asia refers to all the low- and middle-income economies of East \& Southeast Asia and the Pacific, east of and including China and Thailand.

${ }^{\mathrm{c}}$ South Asia consists of Bangladesh, Bhutan, India, Myanmar, Nepal, Pakistan, and Sri Lanka.

${ }^{\mathrm{d}}$ Latin America and the Caribbean refers to all American and Caribbean economies south of the United States.

${ }^{\mathrm{e}}$ Because manufacturing is generally the most dynamic part of the industrial sector, its share of GDP is shown separately.

f 1979

g 1988 .

$\mathrm{NA}=$ Not available

Sources: World Bank (1982: 110-111, 114-115; 1983: 152-153; 1991: 204-205, 208-209, 258-259); and the figures for Taiwan are from CEDP (1991: 3, 4, 23, 29, 41, 199) and DGBAS (1986: 232).

Bank's high-income countries with per capita GNPs of $\$ 10,350$ and $\$ 10,450$, respectively (World Bank 1991:205), while Taiwan (\$7,510) and South Korea $(\$ 4,400)$ are ahead of all other third world nations in per capita income. $^{1}$

These per-capita income figures reveal the dramatic reversals of fortune that have befallen some African and Latin America countries in the 1980s. Between 1980 and 1989, Nigeria, Tanzania, Kenya, and Mexico all had substantial drops in their GNP per capita. Nigeria's decline was the most precipitous, from slightly over $\$ 1,000$ in 1980 to $\$ 250$ in 1989 , while Tanzania's per capita income dropped by more than $50 \%$ and Kenya's by almost 20\%. Mexico's average income in 1989 also declined from its level ten

${ }^{1}$ The Middle East was not included in this discussion because it differs from Third World countries in significant ways. 


\begin{tabular}{|c|c|c|c|c|c|c|}
\hline \multicolumn{4}{|c|}{ Distribution of GDP (percent) } & \multirow[b]{2}{*}{$\begin{array}{l}\text { Life } \\
\text { expectancy } \\
\text { at birth } \\
\text { (years) } \\
1989\end{array}$} & \multirow[b]{2}{*}{$\begin{array}{c}\text { Infant Mortality } \\
\text { Rate (per } 1,000 \\
\text { live births) } \\
1989\end{array}$} & \multirow[b]{2}{*}{$\begin{array}{c}\text { Adult } \\
\text { Illiteracy } \\
\text { (percent) } \\
1985\end{array}$} \\
\hline $\begin{array}{c}\text { Agriculture } \\
1989\end{array}$ & $\begin{array}{c}\text { Industry } \\
1989\end{array}$ & $\begin{array}{c}\text { Manu- } \\
\text { facturing } \\
1989\end{array}$ & $\begin{array}{c}\text { Services } \\
\text { etc } \\
1989\end{array}$ & & & \\
\hline 32 & 27 & 11 & 38 & 51 & 107 & 52 \\
\hline 31 & 44 & 10 & 25 & 51 & 100 & 58 \\
\hline $66^{\mathrm{g}}$ & $7^{\mathrm{g}}$ & $4^{g}$ & $27^{\mathrm{g}}$ & 49 & 112 & NA \\
\hline 31 & 20 & 12 & 49 & 59 & 68 & 41 \\
\hline 24 & 44 & 33 & 34 & 68 & 35 & 29 \\
\hline 32 & 48 & 34 & 20 & 70 & 30 & 31 \\
\hline 10 & 44 & 26 & 46 & 70 & 23 & NA \\
\hline 5 & 44 & 36 & 51 & NA & NA & 10 \\
\hline 32 & 26 & 17 & 41 & 58 & 95 & 59 \\
\hline 30 & 29 & 18 & 41 & 59 & 95 & 57 \\
\hline $10^{\mathrm{g}}$ & $39^{g}$ & $27^{g}$ & $52^{\mathrm{g}}$ & 67 & 50 & 17 \\
\hline $9^{\mathrm{g}}$ & $43^{\mathrm{g}}$ & $31^{\mathrm{g}}$ & $48^{g}$ & 66 & 59 & 22 \\
\hline 9 & 32 & 23 & 59 & 69 & 40 & 10 \\
\hline
\end{tabular}

years earlier, while Brazil's increased by less than $25 \%$. During the same period, the East Asian newly industrializing countries nearly tripled their per capita incomes (Table 1).

Regional divisions of labor in agriculture, industry, and services have emerged within the third world. The sub-Saharan African and South Asian economies place far more emphasis on agriculture and extractive industries, while manufacturing has been the cornerstone of development for the East Asian and Latin American newly industrializing countries. The manufacturing sector's share of GDP in the newly industrializing countries in 1989 ranged from 23\% (Mexico) to $36 \%$ (Taiwan), which is well above the level of the United States, and, in several cases, it is even above Japan's manufacturing/GDP ratio of 30\% (World Bank 1991:209).

By 1989, the East Asian countries had clearly established themselves as the third world's premier exporters, especially of manufactures. Taiwan and South Korea topped the list with $\$ 66.5$ and $\$ 62.3$ billion in exports, respectively, followed by China ( $\$ 52.5$ billion), Brazil ( $\$ 34.4$ billion), and Mexico ( $\$ 23$ billion) (see Table 2). Manufactured products constituted over $90 \%$ of total exports in the East Asian newly industrializing countries and around 70\% of China's and India's exports. For the Latin American nations, manufactures are only about one half to one third of total exports, while in sub-Saharan Africa manufactures are just above $10 \%$ of the export total.

The maturity or sophistication of a country's industrial structure can be measured by the complexity of the products it exports. Here again, the East 


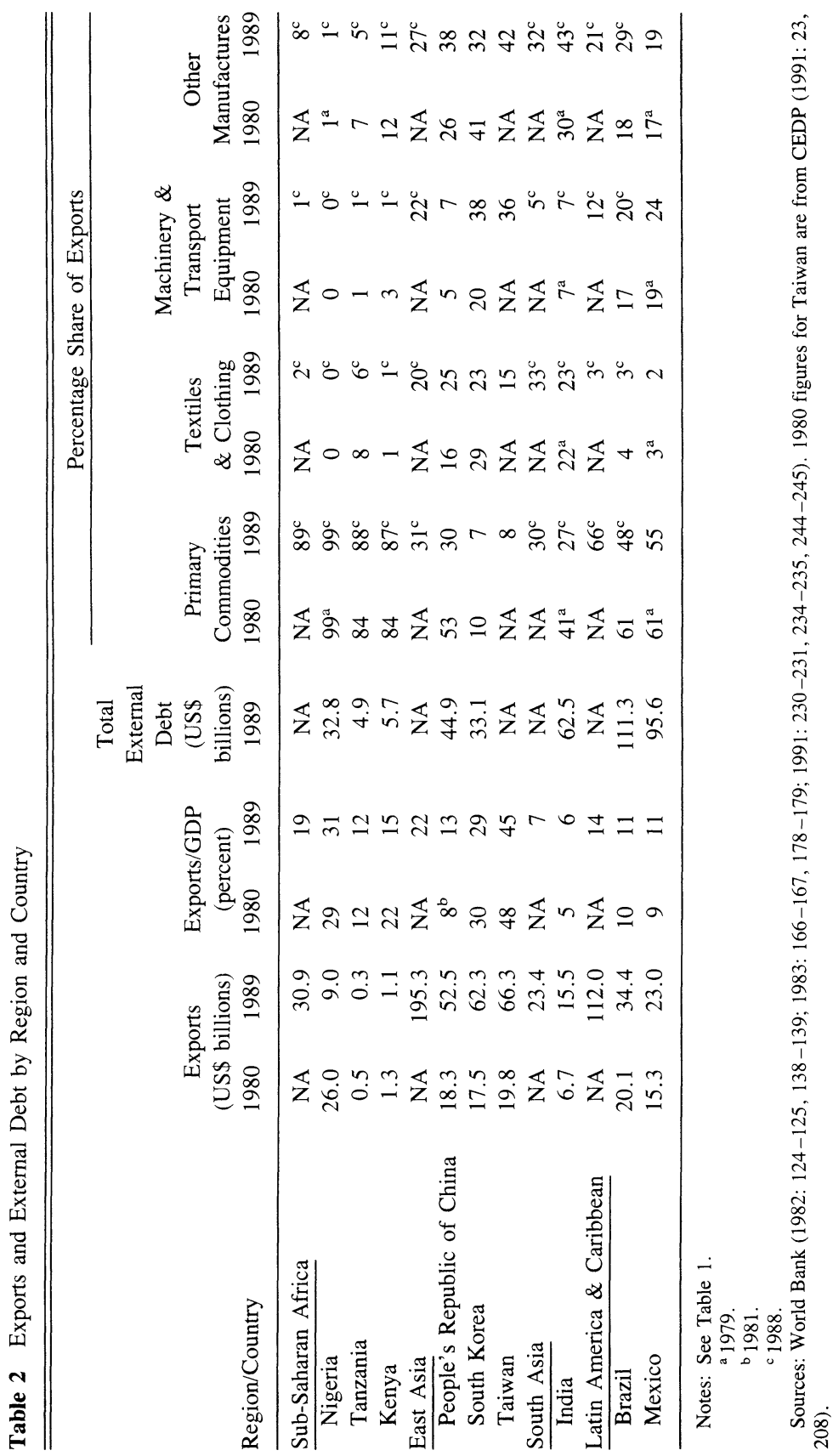


Asian newly industrializing countries are the most advanced. Machinery and transport equipment, which utilize capital- and skill-intensive technology, account for well over one third of their overseas sales. In Mexico and Brazil, this sector represents one fifth to one fourth of total exports (Table 2).

Up to this point, the discussion has focused on economic indicators of change and development. But economic development does not automatically lead to improvements in the standard of living, nor does a lack of economic development mean that living conditions are not getting better.

Three social indicators of development are presented in Table 1: life expectancy at birth, the infant mortality rate, and adult illiteracy. These social indicators match closely the economic patterns already described. The regions of the third world that are worst off economically (sub-Saharan Africa and South Asia) are the same regions with the lowest life expectancy, the highest infant mortality, and the highest adult illiteracy. Conversely, East Asia and Latin America have longer life expectancies, substantially lower rates of infant mortality, and less adult illiteracy.

In summary, third world regions do not conform to a uniform developmental pattern. East Asia has moved well ahead of the other regions during the past decade. Latin America, which was on a par with East Asia ten years ago, has now fallen well behind. Sub-Saharan Africa and South Asia, however, continue to occupy the lowest rungs on the development ladder. In the remainder of this paper, we review selected studies that illustrate why and how this differentiation has occurred.

\section{LATIN AMERICA}

An intense comparative dialogue has emerged between Latin Americanists and East Asianists concerning the relevance of the theories that have been used to explain and interpret each region's development experience. Some of the East Asian specialists have used Latin American theories, especially the dependency and bureaucratic-authoritarian approaches, to frame the discussion of their cases and often to critique the applicability of these theoretical perspectives to East Asia (e.g. Amsden 1979, Barrett \& Whyte 1982, Cumings 1984, Lim 1985, Gold 1986, Kim 1987, Deyo 1989, Haggard 1989). Scholars of Latin America, on the other hand, have been relying on the East Asian cases as an impetus to qualify and revise the theories that originally were developed in a Latin American context (e.g. Evans 1987, Fishlow 1989, Whitehead 1989, Gereffi 1989a,b, Gereffi \& Wyman 1990, Fajnzylber 1990). In addition, the literature on East Asia, even when not explicitly comparative, has attempted recently to place the region's distinctive characteristics in the context of general development theory (e.g. Johnson 1987, Koo 1987, Lincoln \& McBride 1987, Hamilton et al 1987, Hamilton \& Biggart 1988, Amsden 1989, Westney 1989, Wade 1990, Orrú et al 1991). 
Latin America is distinctive, however, in that it was the first third-world region to industrialize, and it followed a development trajectory that relied heavily on multinational corporations to establish its leading industries. Whereas foreign investors in Latin America traditionally concentrated on export-oriented projects in mining, oil, and agriculture, multinational corporations in the post-World War II era emphasized import-substituting investments in advanced manufacturing industries like automobiles, chemicals, machinery, and pharmaceuticals whose output was destined primarily for the relatively large domestic markets in Latin America (Evans 1979, Gereffi \& Evans 1981, Gereffi 1983, Newfarmer 1985, Bennett \& Sharpe 1985, Kaufman 1990). This continuing reliance on foreign direct investment in the development process in Latin America helps to explain why dependency has been a particularly thorny issue for the economies in the region (Stallings 1990).

In the 1970s and 1980s, Latin America's long-standing concerns about investment dependency gave way to a much more acute threat: the debt crisis. External indebtedness in Latin America rose tenfold between 1970 and 1980, from $\$ 23$ billion to $\$ 223$ billion. This debt burden was well beyond the region's absorptive capacity, and it contributed to inflationary pressures and balance of payments disequilibria of unprecedented magnitude (Urquidi 1991). Economic growth in the major Latin American economies came to a virtual standstill during the 1983-1990 period, as the high external debt burden required the allocation of $25 \%$ to $30 \%$ of foreign exchange proceeds merely to cover interest payments. One of Latin America's most prominent economists observed, "Most of the economies in the region were put in a position in which. . . they would be unable easily to resume growth, much less what until then was called 'development.' Zero GDP growth over a period of almost a decade, implying a decline of nearly $10 \%$ in per capita GDP, is an experience that few groups of countries in the world have had in the absence of a serious military defeat" (Urquidi 1991:5).

Even though the major international lenders agreed to implement measures like debt forgiveness and debt-for-equity swaps by the early 1990s in order to spur economic recovery in the region, irreparable damage had already been done. Sustained budget cuts in current expenditures on education and health, the rapid deterioration of basic infrastructure, the curtailment of technological innovation through reduced research and development spending, and the obsolescence of much of the region's industrial plants that had remained idle for nearly a decade led the United Nations Economic Commission on Latin America and the Caribbean to designate the 1980s as the "lost development decade" in Latin America (ECLAC 1990).

Pervasive poverty is a major problem throughout much of the region (Felix 1983). The contrast between the Latin American and East Asian newly 
industrializing countries in this regard could hardly be more striking. Data on household income show that the ratio between the wealthiest $20 \%$ and the poorest $20 \%$ of households is 33 to 1 in Brazil, 20 to 1 in Mexico, 8 to 1 in South Korea, 7.5 to 1 in the United States, 5 to 1 in Taiwan, and 4.3 to 1 in Japan (Gereffi 1990a:14-15). In Brazil, to take a dramatic example, the top $1 \%$ of the population in 1976 received a larger slice of national income than the entire bottom 50\% (Hewlett 1982:321).

Latin America's biggest challenge in the 1990s is to attain higher levels of domestic productivity and international competitiveness while also striving to attain social equity. Fajnzylber (1990) points out that no Latin American country has managed to combine economic growth (defined as a $2.4 \%$ annual rate of increase in per capita GDP) with social equity (defined as a minimum ratio of 0.4 in group income shares of GDP between the bottom $40 \%$ and the top $10 \%$ of the population). Countries in other regions that have met both of these development objectives include: Spain, Portugal, Yugoslavia, Hungary, South Korea, Taiwan, China, and Thailand.

The continued high population growth rates have produced a steady expansion in Latin America's labor force, which has grown on the order of 3.5\% annually. As real demand plunged during the recession of the 1980s, open unemployment led to a booming "underground economy" (Portes et al 1989, Benería \& Roldan 1987). These frequently marginal activities produce no social security or productivity gains and therefore cannot be part of a longterm development strategy. If Latin American manufacturers are going to become internationally competitive, they will have to regard exports as a permanent preoccupation rather than an occasional line of business. In the meantime, multinational corporations probably will generate many of the export opportunities and markets for Latin America's economies. To paraphrase Albert Hirschman, Latin American manufacturers are "late late exporters" (Urquidi 1991). This reliance on multinational corporations, however, threatens to revive many of the long-standing concerns about investment dependence in the region (Gereffi 1989b, Stallings 1990).

\section{EAST ASIA}

Unlike Latin America, the East Asian economies have experienced rapid and sustained economic growth during the past three decades. In large part, this growth was predicated on an earlier turn to outward-oriented development. The decision by the East Asian newly industrializing countries to adopt a strategy of primary or labor-intensive export-oriented industrialization in the mid-1960s was neither inevitable nor easy, but it had a number of positive consequences for these countries. The economic gains in industrial competitiveness, full employment, and high sustained economic growth rates are 
among the most obvious, but equally important is the fact that export-oriented industrialization was spearheaded by local private firms, thus reducing the dependence of the East Asian newly industrializing countries on foreign capital (Haggard \& Cheng 1987, Gereffi 1990b,c). The state in South Korea and Taiwan as well as in Japan has been more effective than its counterparts elsewhere in the developing world because of its ability to discipline big business (Johnson 1982, Amsden 1989, Wade 1990, Gereffi 1990b). This is far more difficult where multinational corporations are the dominant firms, as in Latin America.

From 1973 to 1979, Taiwan and South Korea shifted to secondary importsubstituting industrialization in capital- and technology-intensive fields with an emphasis on defense-related and upstream industries such as steel, heavy machinery, shipbuilding, petrochemicals, computers, and automobiles (Cheng 1990, Haggard 1990, Gereffi \& Wyman 1989). In both countries, advanced import-substitution was selective, and it was designed to sustain rather than supplant national exports as the basis for growth. This facilitated the push into secondary export-oriented industrialization in the 1980s, which was based on a more diversified array of technology- and capital-intensive, high-value-added exports. Secondary export-oriented industrialization allowed the East Asian newly industrializing countries to compete more effectively with the low-wage neighboring Asian countries such as the People's Republic of China, Indonesia, Malaysia, Thailand, and the Philippines, which were moving aggressively to capture the export markets for laborintensive manufactures such as textiles, garments, and footwear (see Gereffi \& Korzeniewicz 1990 on footwear).

In the East Asian newly industrializing countries, the authoritarian governments of South Korea and Taiwan adopted a highly successful "mercantilist" approach to global markets: overseas sales were equated at home with enhanced national security, profitability, and prestige. The favorable external conditions that made the East Asian newly industrializing countries' export success possible-such as rapid economic growth in key overseas markets (especially the United States), a nonprotectionist world trading atmosphere, and low relative wages-are fast disappearing, while the long-suppressed costs of high-speed growth are catching up with these economies.

The local difficulties associated with high-speed growth in East Asia are varied. Taiwan's rapid industrialization in the confines of a small island has created an "environmental nightmare" (Bello \& Rosenfeld 1990:195-214), replete with a wide assortment of toxic wastes that are bespoiling air, water, and land alike. In addition, Taiwan is confronting a serious labor shortage and greater worker militance, which has led Taiwan's capitalists to accelerate their investments in the People's Republic of China and, following Singapore's example, to begin importing foreign workers (current estimates of the 
number of foreign workers in Taiwan range from 50,000 to 100,000 ). Finally, Taiwan also confronts a technological challenge as it tries to move from its conventional labor-intensive exports to heavier and high-tech industries like transportation equipment, electrical machinery, and computer components (Schive 1990).

South Korea has confronted serious insurrections from the working class, whose mobilization was facilitated by the highly concentrated industrial enterprises around which the national economy is built (Cumings 1989, Deyo 1989). The rapid growth of these massive industrial conglomerates (chaebol) in the 1970s and 1980s presents the South Korean state with a major challenge to its power in the economic realm, since the chaebol are trying to free themselves from state control of the financial system in order to chart their own course in global markets (Woo 1991). While the chaebol have been extremely effective in amassing capital and joining borrowed technology to large-scale manufacturing processes based on cheap labor, it remains to be seen whether they can provide an institutional context that encourages true innovation (Amsden 1989).

The key features of East Asia's success may lie less in the area of economic policy than in the region's dynamic institutional arrangements. The East Asian experience has been characterized by: (a) local ownership and control in their leading export and intermediate goods industries; $(b)$ substantial backward and forward linkages within the domestic economy involving a wide variety of local business groups and subcontracting networks (Orrú et al 1991, Hamilton \& Biggart 1988, Hamilton et al 1987); (c) a high level of endogenous technological development, although few of these countries (with the exception of Japan) have made true innovative technological breakthroughs; $(d)$ industrialization by learning "best practice" management techniques from the shopfloor level to the state (Amsden 1989); and (e) state initiatives that "govern" the market, rather than substitute for it (Wade 1990).

\section{SUB-SAHARAN AFRICA}

Since independence, sub-Saharan Africa's development trajectory has been characterized by two main transitions: "from expansion to contraction in economic performance and from optimism to pessimism in political analysis" (Shaw 1991:5). These economic and political trends clearly pose special challenges. First, the sub-Saharan African economy is less stable than the other regions of the third world, a condition that is exacerbated by drought and global recession. Second, the cultures, geography, and political systems of sub-Saharan Africa's 51 countries and territories are exceptionally diverse, making it difficult to generalize about the problems of this region and the policies suitable to change them. 
Nonetheless, there is strong consensus about one topic: African agriculture is suffering. Agricultural production is no longer able to keep pace with population growth, so an increasing number of Africans do not have access to adequate food resources (Berry 1984). Consequently, "the epidemic starvation for all but the very rich" typifying pre-colonial Africa has given way to "endemic undernutrition for the very poor" (Iliffe 1987:6).

The reasons for low agricultural productivity are interrelated. Poor soils, unstable climatic conditions, and inadequate farming techniques to deal with these conditions are a few of the obvious internal constraints on agricultural output (Richards 1983). However, these internal limitations do not receive the critical attention they require because of the greater priority given by public officials to foreign exchange controls, reduction of inflation, and importsubstituting investments. In addition, attempts have been made by African governments to gain political control by usurping productive agricultural enterprises and farmer autonomy (Berry 1984, Bunker 1987). Thus actions by the government and its competing political factions have had the effect of discouraging productivity.

A number of external factors suggest that dependence on agriculture perpetuates sub-Saharan Africa's position in the lowest stratum of the third world. These include the continuation of relationships implemented during colonialism, worsening terms of trade, and changes in global demand for African agricultural products.

The argument addressing exploitative colonial relationships is not new, although there have been recent changes in this perspective. The first part of the argument is that colonialism instituted the reliance of African countries on the overseas sales of one or two primary agricultural products (Amin 1976). Consequently, African economies are now vulnerable to changes in the international terms of trade, global demand, and global pricing. This is as true for extractive commodities (minerals, fuels, and metals) as it is for agriculture (Leys 1982). Furthermore, economic ties of a colonial nature frequently result in the flow of surplus out of the third world. This depletion of resources results in the neglect of development and investment in these regions (Amin 1976, Berry 1984).

The majority of African industries use minimal technology. These include final-stage manufacturing (e.g. automobile assembly in Nigeria and Tanzania) as well as labor-intensive industries (e.g. textiles, apparel and leather). When more advanced technology is required, it is imported, thus further retarding African technological development (Leys 1982). This limits the creation of indigenous backward and forward linkages (Mytelka 1989) and increases the vulnerability of African industries to technological changes in competing regions (Biersteker 1987, Mihyo 1985, Mytelka 1985).

There is skepticism about whether the strategies pursued by African in- 
dustrialists are capable of fostering economic growth at all (Beveridge \& Oberschall 1979, Lubeck 1987). This skepticism represents a shift in focus from external to internal factors contributing to the African crisis (Lubeck 1987). After independence, the majority of capital was invested in agricultural and extractive export commodities (Ollawa 1983). Limited attempts at import-substituting industrialization were made, but this strategy was less successful in Africa than in East Asia or Latin America because the domestic demand for mass-produced commodities was too small, and the scarcity of indigenous sources of technology made it necessary to import most goods (Leys 1982).

Mytelka (1989) claims that import substitution was never actually pursued in Africa. Instead, "import reproduction" was the primary strategy. Import reproduction strategies are those that "ignore the extent to which products incorporate concepts of functionality, cost, quality, and aesthetics that correspond to the producer's principle market of sale" (Mytelka 1989:79). In other words, import reproduction fails to address the needs of the intended market, so that African industrialization was only superficially inward-oriented. As a result, import reproduction in Africa was exhausted by the mid-1970s, while import-substitution continued to bolster economies in other regions of the third world.

Industrialization in Africa has largely been funded by agricultural exports and foreign capital. Agricultural exports have not been sufficient to sustain industrialization owing to worsening terms of trade and declining productivity. This left foreign aid and direct investments by multinational corporations as the primary sources of development capital. Multinational corporations in particular have maintained control over industries through management, technological input, and investment, even after the 1967 period of indigenization in countries such as Nigeria, Kenya, Tanzania and Zaire (Mytelka 1989). Furthermore, the fact that the major economic agents of sub-Saharan African development were foreign capitalists and donors is an important reason why the African economy dramatically worsened in the 1970s and early 1980s with the decline of foreign aid and foreign direct investment.

The influence of foreign capital in parts of sub-Saharan Africa has fostered the emergence of "predatory" capitalism brokered by corrupt states, as exemplified by the cases of Zaire, Uganda, and Sudan (Evans 1989b, Callaghy 1984). According to Evans, "predatory" capitalism exists when "The preoccupation of the political class with rent seeking has turned the rest of society into prey" (Evans 1989b:570). Consequently, the development of a class capable of investing in long-term capitalist enterprises is inhibited.

Economic development in sub-Saharan Africa over the past 20 years has lagged behind that of other regions of the third world. Worsening social development has coincided with poor economic performance. Sub-Saharan 
Africa has the lowest life expectancy, the highest rate of infant mortality, and the highest rate of illiteracy of the four regions examined here. This situation is perpetuated by the tendency of African governments to ignore primary education in favor of higher education. In addition, Africa's infrastructure has been neglected throughout the past 30 years, creating a disincentive for further investment by foreign capital. Rapid population growth and overcrowding in the cities place excess demands on agriculture and the underdeveloped industrial sector. Finally, the unequal distribution of wealth, disparate wages among African laborers, and Africa's long history of poverty (Iliffe 1987) are inimical to the growth of healthy domestic markets. It appears that sub-Saharan Africa is in a situation of long-term decline for which contemporary theories of development have few if any answers.

\section{SOUTH ASIA}

The South Asian economy is slightly better off than that of sub-Saharan Africa in terms of GNP per capita and GDP. However, South Asia accounts for approximately half of the world's poor, which means that it has a higher concentration of people living in poverty than sub-Saharan Africa or any other region of the third world (World Bank 1990:2). To offset the pervasive poverty, South Asian nations have pursued policies to improve access to social services and to encourage development. Sri Lanka, for example, has focused on providing social services, but it has been unable to increase the incomes of the poor due to slow economic growth (World Bank 1990:3). Similarly, a sluggish economy has inhibited the reduction of national poverty and unemployment in India, despite India's attempts at planned development over the past four decades (Bardhan 1984, Sinha 1988). Other countries in South Asia such as Pakistan have been more successful in reducing poverty, but social services have not yet improved (World Bank 1990:3). Consequently, the persistent problem of poverty lends a critical tone to the development trends in South Asia.

Like sub-Saharan Africa, the principal economic activity of the South Asian economies is agriculture. India, however, has periodically over the past 40 years eliminated its need for food imports, due in large part to the remarkable success of the Green Revolution in improving India's crop yields. Conversely, sub-Saharan Africa has not reaped the benefits of a successful Green Revolution and, therefore, continues to rely on imports to lessen the problem of food shortages.

The question of agricultural output in South Asia is often raised in the literature because agricultural trends are posited as an explanation for trends in industry. Ahluwalia (1985), for example, claims that because of the linkages between agriculture and industry, negligible growth in agriculture 
and in the income of agricultural laborers inhibits the demand for industrial products. Furthermore, Mathur claims that an increase in agricultural production is a necessary condition for strengthening industrialization, but it is not sufficient because it must occur in conjunction with a "build up in the capital goods producing capacity of the economy" and the provision of "adequate power, transport infrastructure and institutional finance" (Mathur 1990:275). As a result, the belief that a successful agricultural season is automatically followed by improvements in the industrial sector is incorrect.

The literature on industrial growth in South Asia, and particularly India, is characterized by a mix of pessimism and optimism. The pessimistic point of view highlights India's slowdown in industrial growth since the mid-1970s. This is attributed to India's adoption of the Mahalanobis model, which placed an excessively high priority on heavy industry and underemphasized the labor-intensive activities needed to employ India's massive work force (Sinha 1988). The slowdown in growth also has been explained in terms of the state's inefficient management of the "industrial policy framework," which sheltered industries regardless of costs or quality of production, failed to eliminate protection from competitive sectors, and closed off the economy so that there was little incentive for upgrading products (Ahluwalia 1985).

From the optimistic viewpoint, industrialization in India has progressed toward the desired objective of self-sufficiency because of India's tough stance vis-à-vis foreign capital, its strategy of import-substituting industrialization, and the improvement of indigenous technology (Chelliah 1988). Consequently, India's development has been driven by domestic forces, in contrast to sub-Saharan Africa's relatively greater reliance on foreign aid to generate economic growth.

The principal economic agents in India have been a triple alliance of multinational firms, domestic investors, and the state. Due to the assertive stance of the state in particular, India has demonstrated an ability to wrest segments of its economy from the control of multinational corporations. Grieco (1984), for example, shows how India was able to exploit opportunities provided by intense competition within the international computer industry during the 1970s and thereby increase the benefits for India despite the constraints that often hinder developing host countries in their relations with multinational firms. Grieco's primary argument is that the substantial, albeit incomplete, shift in power away from multinationals to the host country was mediated by the Indian state. Additional factors contributing to this transfer in power were India's large pool of low-wage, highly skilled labor, the overall increase in the number of international suppliers of small systems and inexpensive components, and the success of private indigenous firms that were able to make up for the relative stagnation of India's predominant public sector electronics firm, ECIL. 
In a later study, Encarnation (1989) addresses India's success at actually "dislodging" multinational corporations from domestic markets. Encarnation examines the dynamic relationship between multinationals, the state, and indigenous firms, positing that changes in this relationship enabled India to "increase dramatically both the available range of plausible outcomes and the probability of securing their preferred outcome" (Encarnation 1989:4). For example, multinationals have maintained a bargaining advantage over the state, private indigenous firms, and state-owned firms because they had access to capital and technology necessary for Indian economic development. At the same time, however, the state and private domestic firms have cooperated to acquire control over the domestic market, dislodging multinational corporations through the growth of indigenous firms.

However, in the late 1980s and early 1990s, India changed economic strategies vis-à-vis multinational corporations and adopted "liberal" concessionary policies. Evans' (1989a) explanation of Brazil's comparable experience with the international computer industry provides insight into this recent shift in the balance of power between the Indian state and multinationals. Like India, Brazil pursued assertive policies in the computer industry in the early 1980s, whereby it relied on indigenous firms for its supply of small computers and discouraged imports and domestic production by the multinational companies. But by the late 1980s, Brazil's previously assertive position altered as it acceded to the demands of the multinationals. Stateimposed barriers to foreign firms were lowered, resulting in the domination of the Brazilian market by giant foreign computer companies, such as IBM and Burroughs. Brazil's "pragmatic pursuit of foreign relations goals," Evans argues, "had won over principled defense of economic ideology" (Evans 1989a:231).

Brazil's massive foreign debt and its need to sustain economic growth led to a shift in the balance of power to the advantage of the multinational corporations. Similarly, India has also accrued a substantial foreign debt since the 1970s. India's total external debt was $\$ 7.8$ billion in 1970 , compared to $\$ 18$ billion in 1981 and $\$ 62.5$ billion in 1989 (World Bank 1983:178; World Bank 1991:244). As in the case of Brazil, India's increasing foreign debt burden and its need to generate economic growth have contributed to the liberalization of Indian economic policies in ways designed to attract foreign capital.

\section{IMPLICATIONS FOR DEVELOPMENT THEORY}

Important affinities exist between development theories and the paths of particular third world regions. Development theories are not created in a vacuum; they tend to reflect the experiences of certain countries, regions, 
and time periods that commanded attention when the theories were being elaborated. Consequently, problems may arise when attempts are made to generalize beyond these geographical and historical boundaries.

Development theories were gradually modified and expanded during the 1980s to provide a more integrated look at the manifold changes occurring in the world economy. Many of these transformations require a rethinking of the key suppositions of individual theories in order to capture similarities and contrasts in the experiences of different regions around the globe (Gereffi 1989b). This is an important indicator of the progress or growth of a theory (Wagner \& Berger 1985). Thus, an explicit comparison of regional paths of development facilitates good theory-building. Some of the most significant recent shifts in development theory are highlighted below.

NEOCLASSICAL ECONOMICS East Asia comes closest to embodying the prescriptions of neoclassical economics, although the role of the state is far greater than strict neoclassical interpretations allow (see Wade \& White 1984, Wade 1990). Despite the clear preference of neoclassical economics for export-oriented rather than import-substituting industrialization in the third world, both historical and comparative evidence points to several important lessons concerning national development strategies: $(a)$ import-substituting industrialization and export-oriented industrialization are complementary and interactive sets of policies, rather than mutually exclusive alternatives (Gereffi 1989a, 1990a); (b) both inward-oriented and outward-oriented development strategies are susceptible to systematic constraints or vulnerabilities that prevent either from being a long-term economic panacea (Gereffi 1990c); (c) import substitution was not an unmitigated disaster for Latin America or India, nor was export-oriented industrialization a tribute to unbridled market forces in East Asia (see Bardhan 1984, Fishlow 1989, Whitehead 1989, Dore 1990, Haggard 1990); and (d) a substantial part of the East Asian economic success story seems to be predicated on deliberately "getting relative prices "wrong"" through incentives and subsidies to local businesses that improve their position in the world-economy (Amsden 1989, Wade 1990).

Furthermore, the ordinarily staid international development banks recently have begun to give greater emphasis to the social investments needed to cope with the problems of persistent poverty and social marginality in the third world. In the two most recent World Development Reports, which focus on the themes of poverty (World Bank 1990) and development (World Bank 1991), the World Bank asserts that the productive use of "human capital" calls for policies that harness market incentives to furnish opportunities for the poor and that stress investment in health and education. Similarly, the InterAmerican Development Bank's annual report for 1990 has a special section on "Working Women in Latin America." The region's 40 million working 
women suffer from a lack of training, barriers to credit and technology, and the double burdens of holding a job and running a household, despite their growing importance in the region's work force during the economic crisis of the 1980s (IADB 1990).

WORLD-SYSTEMS/DEPENDENCY THEORIES A growing number of studies have analyzed the dynamic patterns of competition and change in the worldeconomy over the past three decades. Instead of focusing on the categories of core, semiperipheral, and peripheral nations, new research is being done on the international divisions of labor that characterize global industries (Henderson 1989, Gereffi \& Korzeniewicz 1990, Doner 1991). These studies show that the world-economy is indeed hierarchically organized, as world-systems theory postulates, but that the roles played by countries at different levels of development vary according to both the technological characteristics of the industries in question and the industrial strategies followed by nations that seek to move toward higher-value-added activities in global commodity chains (Gereffi \& Korzeniewicz 1990). This approach links the macro-level issues concerning the structure of the world-economy with the meso-level characteristics of national development strategies and the micro-level emphasis on the social embeddedness of international and domestic subcontracting networks in local political and social contexts (Ellison \& Gereffi 1990).

World-systems theory also helps us understand the recent dilemmas confronted by developing nations that try to alter their relationship to the capitalist world-economy. The socialist societies of Eastern Europe are testimony to the difficulties of exiting the world-system; they highlight the kinds of adjustments that will be required to adopt a new role in the global economy. Conversely, sub-Saharan Africa shows that non-incorporation in the worldsystem may bring the severest problems of all. Corrupt states, a weak national bourgeoisie, low levels of foreign investment, small domestic markets, and unstable export industries offer few resources from which to fashion viable development strategies.

The cross-regional comparisons of paths of development in the third world emphasize the need to broaden our views of dependent development (Gereffi \& Wyman 1990, Haggard 1990). The concept of transnational economic linkages is useful in this regard. There are four main transnational economic linkages: foreign aid, foreign trade, foreign direct investment, and foreign debt. Different third world regions have distinct configurations of these external linkages which have led to varied patterns of development outcomes (Gereffi 1989b).

Many countries in Latin America and sub-Saharan Africa, for example, have relied heavily on foreign aid, investments by multinationals, and foreign debt at different stages of their economic trajectories, and these transnational 
linkages were shown to hinder or distort patterns of national development in various ways (Biersteker 1978, Evans 1979, Gereffi 1983, Newfarmer 1985). The East Asian newly industrializing countries, on the other hand, have enjoyed spectacular economic growth despite their dependency on foreign aid (in the 1950s) and foreign trade (since the 1960s), and the Indian state has had considerable success in bargaining with multinationals in the computer industry (Grieco 1984, Encarnation 1989). Dependency theory highlighted the structural constraints implied by transnational economic linkages in the Latin American and African contexts, but it failed to specify the institutional conditions that could lead to successful "dependency management" in the cases of East Asia and India.

A more comprehensive theory of dependency has to focus on the local as well as international conditions that allow domestic actors to use transnational linkages productively and selectively to serve national interests. A key to understanding the success of the East Asian newly industrializing countries and of India, for example, is the performance of diversified and technologically capable locally owned firms that aggressively sought out new export markets and backed the state in its tough bargaining with multinationals. Favorable international circumstances also helped, such as growing world markets for East Asian exports and new competitors in the global computer industry when India made its major gains. Dependency theory is not invalidated by a host country's able management of transnational economic linkages, but the scope of the theory must be expanded to identify the conditions under which "dependency management" can lead to positive development outcomes.

DEVELOPMENTAL STATE Developmental states promote "assertive industrialization," which refers to the use of state policy to force a country's position in the international division of labor to improve at an accelerated pace (Evans 1989a). The idea of assertive industrialization and the bureaucratic mechanisms that support it are found in a wide range of recent empirical studies of third world countries: Brazil (Evans 1979, 1989a, Adler 1987), Mexico (Gereffi 1983, Bennett \& Sharpe 1985), South Korea (Amsden 1989, Woo 1991), Taiwan (Gold 1986, Wade 1990), India (Grieco 1984, Encarnation 1989), Nigeria (Biersteker 1987, Lubeck 1987), and Peru (Becker 1983), plus comparative volumes dealing with Latin America and East Asia (Newfarmer 1985, Deyo 1987, Fajnzylber 1990, Gereffi \& Wyman 1990, Haggard 1990). All these works share what Evans (1989a) terms a post-dependency/ bargaining perspective, which looks at the conflicts between the interests of transnational capital, domestic industrial coalitions, and third world states over local development priorities.

The developmental state approach has been further enhanced by com- 
parative studies that disaggregate the institutional features of economic policy-making in specific regional settings. The research on East Asia, for example, highlights the ideological and organizational coherence of state economic bureaucracies, the policy networks that connect state bureaucracies to the private sector, and the social bases of these political regimes in order to explain variations in industrial adjustment policies within the region (Cheng \& Haggard 1987, Chu 1989, Haggard 1990, Wade 1990).

INSTITUTIONAL ANALYSIS New applications for institutional analysis already have been mentioned in the preceding discussions of global commodity chains, transnational economic linkages, and the developmental state. In addition, the institutional perspective infuses research on third world business networks with a renewed appreciation of the importance of organizational culture and "industrialization by learning" at the micro-level of shop-floor practices.

In East Asia, it has been shown that the interfirm network structure of the major enterprise groups in South Korea, Taiwan, and Japan exhibits intrasocietal isomorphism and intersocietal variation, reflecting the different institutional principles that prevail in each of these three societies (Orrú et al 1991, Hamilton \& Biggart 1988, Hamilton et al 1987). These interfirm linkages may be externalized in international subcontracting networks (Doner 1991), or they can form the basis for dynamic domestic subcontracting ties between large- and small-scale firms, many of which produce for export (Greenhalgh 1984, Amsden 1989). A growing number of studies on the informal economy within Latin America show how people in apparently marginal economic pursuits actually are joined in an integral way with the large firms and public institutions of the formal sector (Beneria \& Roldan 1987, Portes et al 1989).

MARXISM The current decline in the influence of marxian theories undoubtedly is bound up with the dizzying changes connected with "the end of the Cold War." Socialist societies are undergoing profound transformations around the world. The market reforms and ethnic conflicts in Eastern Europe, the disintegration of the Soviet Union, and China's procapitalist reforms and its sudden emergence as one of the world's leading exporters of manufactured goods raise fundamental questions about "remaking the economic institutions of socialism" (Nee \& Stark 1989). The few remaining socialist societies in the third world-Cuba, Tanzania, and Vietnam-are increasingly isolated. However, Tanzania and Vietnam are now forging new ties with international investors, and even North Korea is moving closer to a rapprochement with its capitalist rival to the south.

Ultimately, development concerns quality of life. Our review shows that 
the regions in which agriculture remains dominant (sub-Saharan Africa and South Asia) have the poorest records of economic as well as social wellbeing. However, the experiences of Latin America and India, where poverty abounds despite relatively advanced levels of industrialization, indicate that industrialization per se is no guarantee of high living standards and more equitable patterns of income distribution. Higher levels of economic productivity in agriculture as well as industry, which give rise to improved social welfare, cannot be achieved without significant investments in the health, education, and training of the people who are expected to shoulder the burdens of economic development.

\section{Literature Cited}

Adler, E. 1987. The Power of Ideology: The Quest for Technological Autonomy in Argentina and Brazil. Berkeley: Univ. Calif. Press

Ahluwalia, I. J. 1985. Industrial Growth in India. Dehli: Oxford Univ. Press

Amin, S. 1976. Unequal Development. New York: Monthly Rev.

Amsden, A. H. 1979. Taiwan's economic history: A case of etatisme and a challenge to dependency theory. Mod. China 5:341-80

Amsden, A. H. 1989. Asia's Next Giant: South Korea and Late Industrialization. New York: Oxford Univ. Press

Arrighi, G. 1990. The developmentalist illusion: A reconceptualization of the semiperiphery. See Martin 1990, pp. 11-42

Arrighi, G., Drangel, J. 1986. The stratification of the world-economy: An exploration of the semiperipheral zone. Review 10:9-74

Balassa, B. 1981. The Newly Industrializing Countries in the World Economy. New York: Pergamon

Balassa, B., Bueno, G. M., Kuczynski, P. P., Simonsen, M. H. 1986. Toward Renewed Economic Growth in Latin America. Washington, DC: Inst. Int. Econ.

Bardhan, P. 1984. The Political Economy of Development in India. New York: Basil Blackwell

Barrett, R. E., Whyte, M. K. 1982. Dependency theory and Taiwan: Analysis of a deviant case. Am. J. Sociol. 87(5):1064-89

Becker, D. 1983. The New Bourgeoisie and the Limits of Dependency: Mining, Class and Power in 'Revolutionary' Peru. Princeton, NJ: Princeton Univ. Press

Bello, W., Rosenfeld, S. 1990. Dragons in Distress: Asia's Miracle Economies in Crisis. San Francisco: Inst. Food Dev. Policy

Beneria, L., Roldan, M. 1987. The Crossroads of Class and Gender: Industrial Homework, Subcontracting, and Household
Dynamics in Mexico City. Chicago: Univ. Chicago Press

Bennett, D. C., Sharpe, K. E. 1985. Transnational Corporations Versus the State: The Political Economy of the Mexican Auto Industry. Princeton, NJ: Princeton Univ. Press

Berger, P. L., Hsiao, H-H. M., eds. 1988. In Search of an East Asian Development Model. New Brunswick, NJ: Transaction

Berry, S. 1984. The food crisis and agrarian change in Africa: A review essay. African Stud. Rev. 27(2):59-112

Beveridge, A., Oberschall, A. 1979. African Businessmen and Development in Zambia. Princeton, NJ: Princeton Univ. Press

Biersteker, T. J. 1978. Distortion or Development? Contending Perspectives on the Multinational Corporation. Cambridge, MA: MIT Press

Biersteker, T. J. 1987. Multinationals, the State, and Control of the Nigerian Economy. Princeton, NJ: Princeton Univ. Press

Bradshaw, Y. W. 1988. Reassessing economic dependency and uneven development: The Kenyan experience. Am. Sociol. Rev. 53(5):693-708

Bunker, S. G. 1987. Peasants Against the State: The Politics of Market Control in Bugisu, Uganda, 1900-1983. Chicago: Univ. Chicago Press

Callaghy, T. 1984. The State-Society Struggle: Zaire in Comparative Historical Perspective. New York: Columbia Univ. Press

Chelliah, R. K. 1988. Reflections on Indian political economy and development. See Sinha 1988, pp. 9-28

Cheng, T.-J. 1990. Political regimes and development strategies: South Korea and Taiwan. See Gereffi \& Wyman 1990, pp. 139-78

Cheng, T.-J., Haggard, S. 1987. Newly Industrializing Asia in Transition: Policy Re- 
form and American Response. Berkeley: Inst. Int. Stud., Univ. Calif.

Chu, Y.-H. 1989. State structure and economic adjustment of the East Asian newly industrializing countries. Int. Organ. 43 (4):647-72

Collier, D. ed. 1979. The New Authoritarianism in Latin America. Princeton, NJ: Princeton Univ. Press

Council for Economic Planning and Development (CEPD). 1991. Taiwan Statistical Data Book, 1991. Taipei, Taiwan: CEPD

Cumings, B. 1984. The origins and development of the Northeast Asian political economy: Industrial sectors, product cycles, and political consequences. Int. Organ. 38(1): $1-40$

Cumings, B. 1989. The abortive abertura: South Korea in the light of Latin American experiences. New Left Rev. 173:5-32

Deyo, F., ed. 1987. The Political Economy of the New Asian Industrialism. Ithaca, NY: Cornell Univ. Press

Deyo, F. 1989. Beneath the Miracle: Labor Subordination in the New Asian Industrialism. Berkeley: Univ. Calif. Press

DiMaggio, P. J., Powell, W. W. 1991. Introduction. See Powell \& DiMaggio 1991, pp. $1-38$

Directorate-General of Budget, Accounting \& Statistics (DGBAS). 1986. Statistical Yearbook of the Republic of China. Taipei, Taiwan: Executive Yuan

Doner, R. F. 1991. Driving a Bargain: Automobile Industrialization and Japanese Firms in Southeast Asia. Berkeley: Univ. Calif. Press

Dore, R. 1990. Reflections on culture and social change. See Gereffi \& Wyman 1990, pp. 353-67

Economic Commission for Latin America and the Caribbean (ECLAC), United Nations. 1990. Changing Production Patterns with Social Equity. Santiago, Chile: ECLAC

Ellison, C., Gereffi, G. 1990. Explaining strategies and patterns of industrial development. See Gereffi \& Wyman 1990, pp. 368-403

Encarnation, D. 1989. Dislodging Multinationals: India's Strategy in Comparative Perspective. Ithaca, NY: Cornell Univ. Press

Evans, P. B. 1979. Dependent Development: The Alliance of Multinationals, State and Local Capital in Brazil. Princeton, NJ: Princeton Univ. Press

Evans, P. B. 1987. Class, state, and dependence in East Asia: Some lessons for Latin Americanists. See Deyo 1987, pp. 203-6

Evans, P. B. 1989a. Declining hegemony and assertive industrialization: U.S.-Brazil conflicts in the computer industry. Int. Organ. 43(2):207-38
Evans, P. B. 1989b. Predatory, developmental, and other apparatuses: A comparative political economy perspective on the Third World state. Sociol. Forum 4: 561-87

Evans, P. B., Stephens, J. D. 1988. Development and the world economy. In Handbook of Sociology, ed. N. J. Smelser, pp. 73973. Newbury Park, Calif: Sage

Fajnzylber, F. 1990. Unavoidable Industrial Restructuring in Latin America. Durham, NC: Duke Univ. Press

Felix, D. 1983. Income distribution and the quality of life in Latin America: Patterns, trends, and policy implications. Latin Am. Res. Rev. 18:3-34

Fishlow, A. 1989. Latin American failure against the backdrop of Asian success. See Gourevitch 1989, pp. 117-128

Friedman, D. 1988. The Misunderstood Miracle: Industrial Development and Political Change in Japan. Ithaca, NY: Cornell Univ. Press

Gereffi, G. 1983. The Pharmaceutical Industry and Dependency in the Third World. Princeton, NJ: Princeton Univ. Press

Gereffi, G. 1989a. Development strategies and the global factory. See Gourevitch 1989, pp. 92-104

Gereffi, G. 1989b. Rethinking development theory: Insights from East Asia and Latin America. Sociol. Forum 4:505-33

Gereffi, G. 1990a. Paths of industrialization: An overview. See Gereffi \& Wyman 1990, pp. 3-31

Gereffi, G. 1990b. Big business and the state. See Gereffi \& Wyman 1990, pp. 90-109

Gereffi, G. 1990c. International economics and domestic policies. In Economy and Society: Overviews in Economic Sociology, ed. A. Martinelli, N. Smelser, pp. 231-58. Newbury Park, Calif: Sage

Gereffi, G., Evans, P. 1981. Transnational corporations, dependent development, and state policy in the semiperiphery: A comparison of Brazil and Mexico. Latin Am. Res. Rev. 16(3):31-64

Gereffi, G., Wyman, D. 1989. Determinants of development strategies in Latin America and East Asia. In Pacific Dynamics: The International Politics of Industrial Change, ed. S. Haggard, C. Moon, pp. 23-52. Boulder, Colo: Westview

Gereffi, G., Korzeniewicz, M. 1990. Commodity chains and footwear exports in the semiperiphery. See Martin 1990, pp. 45-68

Gereffi, G., Wyman, D., eds. 1990. Manufacturing Miracles: Paths of Industrialization in Latin America and East Asia. Princeton, NJ: Princeton Univ. Press

Gold, T. B. 1981. Dependent development in Taiwan. PhD thesis, Harvard Univ. Cambridge, Mass. 
Gold, T. B. 1986. State and Society in the Taiwan Miracle. Armonk, NY: Sharpe

Gourevitch, P. A. ed. 1989. The Pacific Region: Challenges to policy and theory. Special issue of the Ann. Am. Acad. Polit. Soc. Sci. 505.

Granovetter, M. 1985. Economic action and social structure: The problem of embeddedness. Am. J. Sociol. 91(3):481-510

Greenhalgh, S. 1984. Networks and their nodes: Urban society on Taiwan. China $Q$. 99:529-52

Grieco, J. 1984. Between Dependency and Autonomy: India's Experience with the International Computer Industry. Berkeley: Univ. Calif. Press

Haggard, S. 1989. The political economy of foreign direct investment in Latin America. Latin Am. Res. Rev. 24(1):184-208

Haggard, S. 1990. Pathways from the Periphery: The Politics of Growth in the Newly Industrializing Countries. Ithaca, NY: Cornell Univ. Press

Haggard, S., Cheng, T.-J. 1987. State and foreign capital in the East Asian NICs. See Deyo 1987, pp. 84-135

Hamilton, G. G., Kao, C-S. 1987. Max Weber and the analysis of East Asian industrialization. Int. Sociol. 2:289-300

Hamilton, G. G., Orrú, M., Biggart, N. W. 1987. Enterprise groups in East Asia: An organizational analysis. Finan. Econ. Rev. (Tokyo, Japan) 161:78-106

Hamilton, G. G., Biggart, N. W. 1988. Market, culture, and authority: A comparative analysis of management and organization in the Far East. Am. J. Sociol. 94 (Suppl.): S52-S94

Henderson, J. 1989. The Globalisation of High Technology Production: Society, Space and Semiconductors in the Restructuring of the Modern World. London: Routledge

Hewlett, S. A. 1982. Poverty and inequality in Brazil. In Brazil and Mexico: Patterns in Late Development, ed. S. A. Hewlett, R. B. Weinert, pp. 317-38. Philadelphia, Penn: Inst. Study Hum. Issues

Iliffe, J. 1987. The African Poor. Cambridge: Cambridge Univ. Press

Inter-American Development Bank (IADB). 1990. Economic and Social Progress in Latin America:1990 Report. Baltimore, Md: Johns Hopkins Univ. Press

Johnson, C. 1982. MITI and the Japanese Miracle. Stanford, Calif: Stanford Univ. Press

Johnson, C. 1987. Political institutions and economic performance: The governmentbusiness relationship in Japan, South Korea, and Taiwan. See Deyo 1987, pp. 134-64

Kaufman, R. 1990. How societies change development models or keep them: Reflec- tions on the Latin American Experience in the 1930s and the postwar world. See Gereffi \& Wyman 1990, pp. 110-138

Kim, K.-D., ed. 1987. Dependency Issues in Korean Development. Seoul, Korea: Seoul Natl. Univ. Press

Koo, H. 1987. The interplay of state, social class, and world system in East Asian Development: The cases of South Korea and Taiwan. See Deyo 1987, pp. 165-81

Leys, C. 1982. African economic development in theory and practice. Daedalus 3:99124

Lim, H.-C. 1985. Dependent Development in Korea, 1963-1979. Seoul, Korea: Seoul National Univ. Press

Lincoln, J., McBride, K. 1987. Japanese industrial organization in comparative perspective. Annu. Rev. Sociol. 13:289-312

Lubeck, P., ed. 1987. The African Bourgeoisie: Capitalist Development in Nigeria, Kenya and the Ivory Coast. Boulder, Colo: Lynne Rienner

Martin, W., ed. 1990. Semiperipheral States in the World-Economy. Westport, Conn: Greenwood

Mathur, A. 1990. The interface of agricultural and industrial growth in the development process: Some facets of the Indian experience. Dev. Change 22:247-80

Meyer, J. W., Rowan, B. 1991. Institutionalized organizations: Formal structure as myth and ceremony. See Powell \& DiMaggio 1991, pp. 41-62

Mihyo, P. 1985. Bargaining for technology in Tanzania's public enterprises: Some policy issues. Study prepared for the IDRC, Ottawa

Mytelka, L. K. 1985. Stimulating effective technology transfer: The case of textiles in Africa. In International Technology Transfer: Concepts, Measures \& Comparisons, ed. N. Rosenberg, C. Frischtak, pp. 77125. New York: Praeger

Mytelka, L. K. 1989. The unfulfilled promise of African industrialization. African Stud. Rev. 32(3):77-137

Nee, V., Stark, D., eds. 1989. Remaking the Economic Institutions of Socialism: China and Eastern Europe. Stanford, Calif: Stanford Univ. Press

Newfarmer, R., ed. 1985. Profits, Progress and Poverty: Case Studies of International Industries in Latin America. Notre Dame, Ind: Univ. Notre Dame Press

O’Donnell, G., Schmitter, P., Whitehead, L., eds. 1986. Transitions from Authoritarian Rule. Baltimore, Md: Johns Hopkins Univ. Press

Ollawa, P. 1983. The political economy of development: A theoretical reconsideration of some unresolved issues. African Stud. Rev. 26(1):125-55 
Orrú, M., Biggart, N. W., Hamilton, G. G. 1991. Organizational isomorphism in East Asia. See Powell \& DiMaggio 1991, pp. 361-89

Portes, A., Castells, M., Benton, L. A., eds. 1989. The Informal Economy: Studies in Advanced and Less Developed Countries. Baltimore, Md: Johns Hopkins Univ. Press

Powell, W. W., DiMaggio, P. J., eds. 1991. The New Institutionalism in Organizational Analysis. Chicago, Ill: Univ. Chicago Press

Richards, P. 1983. Farming systems and agrarian change in West Africa. Prog. Hum. Geogr. 7(1):1-39

Schive, C. 1990. The next stage of industrialization in Taiwan and South Korea. See Gereffi \& Wyman 1990, pp. 26791

Shaw, T. M. 1991. Reformism and revisionism in African political economy in the 1990s. Pres. Int. Stud. Assoc. Annu. Meet., Vancouver, Canada

Sinha, R. K., ed. 1988. Economic Policy and Development in India. New Delhi: Deep \& Deep

So, A. Y. 1990. Social Change and Development: Modernization, Dependency, and World-System Theories. Newbury Park, Calif: Sage

Stallings, B. 1990. The role of foreign capital in economic development. See Gereffi \& Wyman 1990 , pp. 55-89

Stepan, A. 1988. Rethinking Military Politics: Brazil and the Southern Cone. Princeton, NJ: Princeton Univ. Press

Swidler, A. 1986. Culture in action: Symbols and strategies. Am. Sociol. Rev. 51(2):27386

Urquidi, V. L. 1991. The prospects for economic transformation in Latin America: Opportunities and resistances. LASA Forum 22(3):1-9

Valenzuela, J. S., Valenzuela, A. 1978. Modernization and dependency: Alternative per- spectives in the study of Latin American underdevelopment. Comp. Polit. 10:535-57

Wade, R. 1990. Governing the Market: Economic Theory and the Role of Government in East Asian Industrialization. Princeton, NJ: Princeton Univ. Press

Wade, R., White, G., eds. 1984. Developmental states in East Asia: Capitalist and socialist. Inst. Dev. Stud. Bull. 15:1-70

Wagner, D. G. , Berger, J. 1985. Do sociological theories grow? Am. J. Sociol. 90(4):697-728

Wallerstein, I. 1974. The Modern WorldSystem, I: Capitalist Agriculture and the Origins of the European World-Economy in the Sixteenth Century. New York: Academic

Wallerstein, I. 1979. The Capitalist WorldEconomy. New York: Cambridge

Wallerstein, I. 1989. The Modern WorldSystem, III: The Second Era of Great Expansion of the Capitalist World-Economy, 1730s-1840s. New York: Academic

Westney, D. E. 1989. Sociological approaches to the Pacific region. See Gourevitch 1989, pp. 24-33

Whitehead, L. 1989. Tigers in Latin America? See Gourevitch 1989, pp. 142-51

Williamson, O. E. 1985. The Economic Institutions of Capitalism. New York: Free Press

Woo, J. 1991. Race to the Swift: State and Finance in Korean Industrialization. New York: Columbia Univ. Press

World Bank. 1982. World Development Report 1982. New York: Oxford Univ. Press

World Bank. 1983. World Development Report 1983. New York: Oxford Univ. Press

World Bank. 1987. World Development Report 1987. New York: Oxford Univ. Press

World Bank. 1990. World Development Report 1990. New York: Oxford Univ. Press

World Bank. 1991. World Development Report 1991. New York: Oxford Univ. Press 